\title{
Chemical Constituents of Geum urbanum L. Roots
}

Ton, Quang That; Van Nguyen Thien, Truong ; Dang, Huu Phuc; Ngoc , Le Hoan; Loan, Kieu Thi Vo; Nguyen, Minh Huu Duc; Ngu, Nhan Truong; Nguyen, Thien S. ; Hansen, Poul Erik

Published in:

Natural Product Research

DOI:

10.1080/14786419.2018.1425844

Publication date:

2018

Document Version

Peer reviewed version

Citation for published version (APA):

Ton, Q. T., Van Nguyen Thien, T., Dang, H. P., Ngoc , L. H., Loan, K. T. V., Nguyen, M. H. D., Ngu, N. T., Nguyen, T. S., \& Hansen, P. E. (2018). Chemical Constituents of Geum urbanum L. Roots. Natural Product Research, 32(21), 1-6. https://doi.org/10.1080/14786419.2018.1425844

\section{General rights}

Copyright and moral rights for the publications made accessible in the public portal are retained by the authors and/or other copyright owners and it is a condition of accessing publications that users recognise and abide by the legal requirements associated with these rights.

- Users may download and print one copy of any publication from the public portal for the purpose of private study or research.

- You may not further distribute the material or use it for any profit-making activity or commercial gain.

- You may freely distribute the URL identifying the publication in the public portal.

Take down policy

If you believe that this document breaches copyright please contact rucforsk@kb.dk providing details, and we will remove access to the work immediately and investigate your claim. 


\section{Chemical Constituents of Geum urbanum L. Roots}

Quang Ton That ${ }^{\mathrm{a}}$, Truong Van Nguyen Thien ${ }^{\mathrm{a}}$, Huu Phuc Dang, ${ }^{\mathrm{c}, \text {, }}$, Ngoc Le Hoan ${ }^{\mathrm{a}}$, Loan Kieu Thi Vo ${ }^{\mathrm{a}}$, Minh Huu Duc Nguyen ${ }^{\mathrm{e}}$, Nhan Truong Ngu ${ }^{\mathrm{f}}$, Thien S. Nguyen ${ }^{\mathrm{c}}$, Poul Erik Hansen ${ }^{\mathrm{b}}$

\section{Affiliation}

${ }^{a}$ Faculty of Chemistry, VNUHCM-University of Science, 227 Nguyen Van Cu Street, District 5, Ho Chi Minh City, Vietnam.

${ }^{\mathrm{b}}$ Dept of Science and Environment, Roskilde University, Universitetsvej 1, P.O. Box 260, DK4000 Roskilde, Denmark.

'Theoretical Physics Research Group, Ton Duc Thang University, Ho Chi Minh City, Viet Nam

${ }^{\mathrm{d}}$ Faculty of Applied Sciences, Ton Duc Thang University, 19 Nguyen Huu Tho Street, Tan Phong District, Ho Chi Minh City, Vietnam.

${ }^{\mathrm{e}}$ Faculty of Traditional Medicine, University of Medicine and Pharmacy at Ho Chi Minh City, Ho Chi Minh City, Vietnam.

${ }_{\mathrm{f}}^{\mathrm{f}}$ aculty of National Science and Technology, Tay Nguyen University, Buon Ma Thuot City, Dak Lak, Vietnam.

* Correspondence to: Huu Phuc Dang

E-mail: danghuuphuc@tdt.edu.vn

Tel: +84909041387 


\section{ABSTRACT}

A new dehydrodigallic acid derivative (1), along with 19 known compounds, including 6 phenolic derivatives, 2 steroids, and 11 triterpenoids were isolated from the ethanol extract of the root of Geum urbanum. Herein, there is the first report of steroid and triterpene in Geum urbanum. The purified metabolites were characterized by NMR spectroscopic and mass spectrometric analyses. The identification of the known compounds (2-20) was based on the comparison of their NMR spectroscopic features with previously published data. The structural characteristics of compound $\mathbf{1}$ were elucidated by comprehensive 1D and 2D NMR spectroscopic methods, and acid hydrolysis.

Keyword: dehydrodigallic acid derivative, triterpenoid, Geum urbanum, ellagic acid derivatives 


\section{Introduction}

Geum urbanum L. (Wood Avens) is a perennial pubescent herb with a short, thick rhizome and a member of Rosaceae family, native to Eurasian Temperate Zone. It is commonly distributed throughout the British Isles but absents from the Shetland and parts of northern Scotland. The species spreads from southern Norway, Sweden, Finland, and Russia to the Mediterranean. Outside Europe, it exists eastwards to Asia, western Siberia, and the Himalaya, and expands along northwest African coast from west of Algiers to the Tunisia (Taylor 1997). Geum urbanum has long been used in traditional European medicine for treatment of stomach complaints (Fournier 1947), gingivitis and inflammation of mucous membranes (Fournier 1947, Menković et al. 2011).

Main compounds, isolated from the roots of this herb, were ellagitannins (tellimagrandin, stachyurin, casuarynin and gemin A, and ellagic acid derivatives), procyanidins (procyanidin B3, procyanidin C2, and catechin derivatives) (Granica et al. 2016, Piwowarski et al. 2014), gallic acid, vanillic acid (Granica, Kłębowska, Kosiński, Piwowarski, Dudek, Kaźmierski and Kiss 2016), gein, and vicianose (Pšenák et al. 1972). In this report, monophenolic compounds, gein, and ellagic acid derivatives were also collected. However, one new dehydrodigallic acid derivative, steroids, and triterpenoids were isolated for the first time in Geum and their structures were identified based on NMR spectroscopic methods.

\section{Results and discussion}

By implementing repeatedly silica gel and Sephadex LH-20 column chromatographic separation, and preparative $\mathrm{HPLC}$ on $\mathrm{CHCl}_{3}$ and EtOAc fractions from the original ethanol extract of Geum urbanum roots, a new compound (1) and 19 known (2-20) phenolics, steroids, and triterpenoids of the oleanane, ursane types have been isolated. The new compound (1) was identified as a dehydrodigallic derivative as supported by, acid hydrolysis and 1D and 2D NMR spectroscopic, and mass spectrometric techniques (Table S1, Figure 1). The known compounds 
were identified as gallic acid (2) (Eldahshan 2011), vanillic acid (3) (Phan Duc et al. 2016), isovanillic acid (4) (Ding et al. 2000), gein (5) (Shahani et al. 2012), 3,3',4'-tri- $O$-methylellagic acid (6) (Gao et al. 2014), 3,3',4'-tri- $O$-methylellagic acid 4- $O-\beta$-D-glucopyranoside (7) (Gao, Wu, Zou and Dai 2014), pomonic acid (8) (Cheng and Cao 1992), 19 $\alpha$-hydroxy-3-oxoursa1,12-dien-28-oic acid (9) (Traoré-Coulibaly et al. 2009), ursolic acid (10) (Othman et al. 1996), 2a,3 $\alpha, 24$-trihydroxyursa-12,18-dien-28-oic acid (11) (Yuan et al. 2008), rubuside A (12) (Li et al. 2009), rubuside D (13) (Li, Fu, Bai, Sasaki, Kato and Koike 2009), $\beta$-sitosterol (14) (Atiku et al. 2009), $\beta$-sitosterol 3-O- $\beta$-D-glucopyranoside (15) (Mizushina et al. 2006), oleanolic acid (16) (Guvenalp et al. 2006), niga-ichigoside F1(17) (Shigenaga et al. 1985), arjunglucoside I

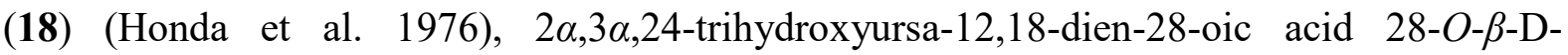
glucopyranoside (19) (Li, Fu, Bai, Sasaki, Kato and Koike 2009), and 2 $\alpha, 3 \beta, 23$-trihydroxyursa12,19(29)-dien-28-oic acid 28-O- $\beta$-D-glucopyranoside (20) (Li, Fu, Bai, Sasaki, Kato and Koike 2009) (Figure S2) by comparison of their spectroscopic data and literature values.

Compound 1 was obtained as a white powder. The molecular formula of $\mathrm{C}_{15} \mathrm{H}_{12} \mathrm{O}_{10}$ was assigned for this compound based on HR-ESI-MS analysis $\left([\mathrm{M}+\mathrm{Na}]^{+} \mathrm{m} / z\right.$ 375.0338, calcd 375.0328). The ${ }^{1} \mathrm{H}-\mathrm{NMR}$ spectrum (Table $\mathrm{S} 1$ ) displayed resonances for three aromatic protons $\delta_{\mathrm{H}} 7.22(1 \mathrm{H}, d, 2.0, \mathrm{H}-6), 7.06\left(1 \mathrm{H}, s, \mathrm{H}-4^{\prime}\right), 6.72(1 \mathrm{H}, d, 2.0, \mathrm{H}-2)$, and a methoxy group $\delta_{\mathrm{H}}$ 3.68 $(3 \mathrm{H}, s)$. The ${ }^{13} \mathrm{C}-\mathrm{NMR}$ along with DEPT-NMR indicated the existence of fifteen carbons, among which there were two carboxyl groups at $\delta_{\mathrm{C}} 170.1$ and $\delta_{\mathrm{C}} 167.6$, and one methoxy group at $\delta_{\mathrm{C}}$ 52.2. The HMBC correlations between H-2/C-1, H-2/C-3, H-2/C-4, H-2/C-6, H-2/으으, H-6/C-2, H-6/C-4, H-6/C-5, and H-6/ $\underline{\mathbf{C O O H}}$ were observed (Figure S1), which indicated the presence of a tetrasubstituted benzene ring. Moreover, the pentasubstituted aromatic ring was deduced based on the HMBC correlations between H-6'/C-1', H-6'/C-2', H-6'/C-3', H-6'/C-4',

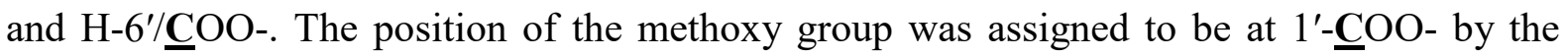
observed HMBC correlations. The ${ }^{1} \mathrm{H}$ and ${ }^{13} \mathrm{C}$ NMR spectra of 1 resembled closely those of 
dehydrodigallic acid derivatives, isolated from Geum urbanum (Piwowarski, Granica, Kosiński and Kiss 2014, Yoshida et al. 1985). Additionally, normal acid hydrolysis ( $\mathrm{HCl} 2 \mathrm{~N}, 15$ mins, $100^{\circ} \mathrm{C}$ ) yielded dehydrodigallic acid with melting point of $362^{\circ} \mathrm{C}$ (Nawwar et al. 2009). Thus, the structure of mono-methyl dehydrodigallate (1) was concluded as shown (Figure 1).

[table S1 and figure 1 near here]

In the genus Geum, almost of tritepenoids, belong to olean and ursane skeleton, were evaluated biological activities such as antiviral, anticoagulant, and myogenic effects (Cheng et al. 2011). Nigaichigoside F1, ursane-type triterpenoid, was isolated from Geum japonicum, which stimulates the regenerative potential of a damaged muscle (Cheng et al. 2006), and hence it could be treat myocardial infarctions. From the EtOAc extract of Geum japonicum, $2 \alpha, 3 \beta, 19 \alpha, 23$-tetrahydroxyurs-12-en-28-oic acid showed potent anticoagulant effect (Zeng et al. 1998); and two ursane-type triterpenes (2R,19R-dihydroxy-3-oxo-12-ursen-28-oic acid and ursolic acid) and an olean-type one (maslic acid) exhibited significant HIV-1 protease inhibitory activity (Xu et al. 2000, Xu et al. 1996). Oleanolic acid and arjunolic acid (two oleantype triterpenes) showed antitumor activity against Ehrlich and intestinal cells, respectively (Elsherbiny and Al-Gayyar 2016, Liu 1995). Thus, all isolated triterpenoids from the chloroform and ethyl acetate extracts of Geum urbanum could be showed potent biological activities.

\section{Experimental}

\subsection{General Experimental Procedures}

The HR-ESI-MS was determined with a MicrOTOF QII mass spectrometer (Bruker Daltonics). The NMR spectra were recorded on a Bruker Avance III 500 spectrometer with TMS as an internal standard, and the chemical shifts are expressed as $\delta$ values. Column chromatography was carried out using silica gel 60, 0.06-0.2 mm (Scharlau, Barcelona, Spain) and LiChroprep ${ }^{\circledR}$ RP-18, 40-63 $\mu \mathrm{m}$ (Merck KGaA, Darmstadt, Germany). Analytical and 
preparative TLC was carried out on precoated Kieselgel $60 \mathrm{~F}_{254}$ or $\mathrm{RP}_{18}$ plates (Merck KGaA, Darmstadt, Germany). Other chemicals were of the highest grade available.

\subsection{Plant Material}

The roots of Geum urbanum L. were collected at Roskilde University, Denmark in August 2010. The plant was identified by botanist Hoang Viet. A voucher specimen (BP002) was deposited in the herbarium of the Department of Organic Chemistry, VNUHCM-University of Science.

\subsection{Extraction and Isolation}

Dried root Geum urbanum $(3.0 \mathrm{~kg})$ was exhausted with ethanol, the ethanol solution was evaporated under reduced pressure. The ethanol residue was suspended in $\mathrm{H}_{2} \mathrm{O}$ and successively partitioned with $n$-hexane $(\mathrm{H})$, chloroform $(\mathrm{C})$, ethyl acetate (EA), to yield the $n$ hexane (7.2 g), chloroform (50.1 g), ethyl acetate $(58.7 \mathrm{~g})$ and aqueous (108.1 g) extracts, respectively.

The ethyl acetate extract (58.7 g) was subjected to silica gel column chromatography and eluted with H-EA mixtures $(7: 3$ to $0: 10, \mathrm{v} / \mathrm{v})$ and $\mathrm{EA}: \mathrm{MeOH}(10: 0$ to $0: 10, \mathrm{v} / \mathrm{v})$, to afford six fractions (EA1-6). Fraction EA1 (4.0 g) was chromatographed over silica gel column with H-EA (8:2 to 0:10, v/v), to yield five subfractions (EA1.1-EA1.5). Subfraction EA1.2 (760 mg) was subjected to ODS column, eluted with $\mathrm{MeOH}-\mathrm{H}_{2} \mathrm{O}(6: 4, \mathrm{v} / \mathrm{v})$, to afford 8 (8.0 mg), and 9 (11.0 mg). Subfraction EA1.3 (830 mg) purified by preparative TLC with H-EA-MeOH (4:6:1), to yield 2 (10.0 mg), and $11(10.0 \mathrm{mg})$. Fraction EA3 (7.74 g) was subjected to silica gel column chromatography, eluted with EA-MeOH (10:0 to 0:10, v/v), to yield five subfractions (EA3.1EA3.5). Subfraction EA3.1 (590 mg) were subjected to silica gel column chromatography, eluted with $\mathrm{C}: \mathrm{MeOH}$ (9:1 to 0:10), to yield $1(10.0 \mathrm{mg}), \mathbf{1 2}(5.0 \mathrm{mg}), \mathbf{1 3}(4.3 \mathrm{mg})$, and 15 (4.0 $\mathrm{mg})$. Subfraction EA3.5 (180 mg) were chromatographed over silica gel column with C:MeOH (8:2 to 0:10), to afford three subfractions $17(20.0 \mathrm{mg})$, and $18(11.0 \mathrm{mg})$. 
The chloroform extraction (50.1 g) was subjected to silica gel column chromatography, eluted with gradient H-EA $(10: 0-0: 10, v / v)$ and EA-MeOH $(10: 0-0: 10, v / v)$, to afford thirteen fractions (C1-13). Fraction C5 (1.29 g) was separated over a sephadex LH-20 column with C:MeOH (5:5, v/v), to yield seven subfractions (C5.1- C5.7). Subfraction C5.4 (381.1 mg) was subjected to silica gel column chromatograph with C:EA $(8: 2$ to $0: 10, \mathrm{v} / \mathrm{v})$, to afford $4(15.7$ $\mathrm{mg})$, and 6 (3.2 mg). Fraction C10 (1.37 g) was subjected to silica gel column chromatography, eluted with H-EA mixtures (9:1-0:10), to yield nine subfractions (C10.1-C10.9). Subfraction C10.3 (125.4 mg) purified by preparative TLC with $\mathrm{H}-\mathrm{C}-\mathrm{MeOH}(4: 6: 0,5)$, to afford $\mathbf{1 0}(5,3$ mg), 3 (6,6 mg). Fractions C11 (1.95 g) was subjected to silica gel column chromatography, and eluted gradient $\mathrm{C}-\mathrm{MeOH}$ (9:10-0:10), to yield six subfractions (C11.1-6). Subfraction C11.4 (265.8 mg) were chromatographed over silica gel column with C-EA-MeOH (5:4:1), to yield 6 (4,7 mg), $7(5,6 \mathrm{mg})$ and $\mathbf{5}(5,8 \mathrm{mg})$.

3,4-Dihydroxy-5-(2,3,6-trihydroxy-5-methoxycarbonylphenoxy)benzoic acid (1): white powder; ${ }^{1} \mathrm{H}-\mathrm{NMR}\left(\mathrm{CD}_{3} \mathrm{OD}, 500 \mathrm{MHz}\right), \delta$ (ppm): $7.22(1 \mathrm{H}, d, 2.0, \mathrm{H}-6), 7.06(1 \mathrm{H}, s, \mathrm{H}-5$ ) $), 6.72$ $(1 \mathrm{H}, d, 2.0, \mathrm{H}-2), 3.68\left(3 \mathrm{H}, s, 6{ }^{\prime}-\mathrm{COOCH}_{3}\right) ;{ }^{13} \mathrm{C}-\mathrm{NMR}\left(\mathrm{CD}_{3} \mathrm{OD}, 125 \mathrm{MHz}\right), \delta(\mathrm{ppm}): 170.1(1-$ COOH), 167.6 (6'-COO), 148.5 (C-3), 146.7 (C-5), 143.8 (C-4'), 140.9 (C-3'), 140.9 (C-2'), 140.5 (C-4), 138.0 (C-1'), 121.8 (C-1), 115.1 (C-6'), 112.3 (C-6), 109.9 (C-5'), 108.3 (C-2), $52.2\left(6^{\prime}-\mathrm{OCH}_{3}\right) ;(+)-H R E S I M S \mathrm{~m} / \mathrm{z} 375.0338[\mathrm{M}+\mathrm{Na}]^{+}$(calcd for $\left.\mathrm{C}_{15} \mathrm{H}_{12} \mathrm{NaO}_{10}, 375.0328\right)$.

\section{Supplementary material}

1D and 2D NMR and (+)-HRESIMS spectra for the new compound $\mathbf{1}$.

\section{References}

Atiku I, Musa AM, Sule MI. 2009. Isolation of stigmasterol, $\beta$-sitosterol and 2hydroxyhexadecanoic acid methyl ester from the rhizomes of Stylochiton lancifolius pyer and kotchy (Araceae). Niger J Pharm Sci.7:19-25.

Cheng D-L, Cao X-P. 1992. Pomolic acid derivatives from the root of Sanguisorba officinalis. Phytochemistry.31:1317-1320.

Cheng L, Gu X, Sanderson JE, Wang X, Lee K, Yao X, Liu H, Cheung WL, Li M. 2006. A new function of a previously isolated compound that stimulates activation and differentiation 
of myogenic precursor cells leading to efficient myofiber regeneration and muscle repair. The International Journal of Biochemistry \& Cell Biology.38:1123-11133.

Cheng X-R, Jin H-Z, Qin J-J, Fu J-J, Zhang W-D. 2011. Chemical Constituents of Plants from the Genus Geum. Chem Biodivers.8:203-222.

Ding H-Y, Lin H-C, Teng C-M, Wu Y-C. 2000. Phytochemical and pharmacological studies on Chinese Paeonia Species. J Chin Chem Soc.47:381-388.

Eldahshan OA. 2011. Isolation and structure elucidation of phenolic compounds of carob leaves grown in Egypt. Curr Res J Biol Sci.3:52-55.

Elsherbiny NM, Al-Gayyar MMH. 2016. Anti-tumor activity of arjunolic acid against Ehrlich Ascites Carcinoma cells in vivo and in vitro through blocking TGF- $\beta$ type 1 receptor. Biomed Pharmacother.82:28-34.

Fournier P. 1947. Le Livre des Plantes Médicinales et Vénéneuses de France. Paris: Société Linnéenne de Lyon.

Gao X, Wu J, Zou W, Dai Y. 2014. Two ellagic acids isolated from roots of Sanguisorba officinalis L. Promote hematopoietic progenitor cell proliferation and megakaryocyte differentiation. Molecules.19:5448-5458.

Granica S, Kłębowska A, Kosiński M, Piwowarski JP, Dudek MK, Kaźmierski S, Kiss AK. 2016. Effects of Geum urbanum L. root extracts and its constituents on polymorphonuclear leucocytes functions. Significance in periodontal diseases. J Ethnopharmacol.188:1-12.

Guvenalp Z, Kilic N, Kazaz C, Kaya Y, Dem Irezer LOu. 2006. Chemical constituents of Galium tortumense. Turk J Chem.30:515-523.

Honda T, Murae T, Tsuyuki T, Takahashi T, Sawai M. 1976. Arjungenin, arjunglucoside I, and arjunglucoside II. A new triterpene and new triterpene glucosides from Terminalia arjuna. Bull Chem Soc Jpn.49:3213-3218.

Li W, Fu H, Bai H, Sasaki T, Kato H, Koike K. 2009. Triterpenoid Saponins from Rubus ellipticus var. obcordatus. J Nat Prod.72:1755-1760.

Liu J. 1995. Pharmacology of oleanolic acid and ursolic acid. J Ethnopharmacol.49:57-68.

Menković N, Šavikin K, Tasić S, Zdunić G, Stešević D, Milosavljević S, Vincek D. 2011. Ethnobotanical study on traditional uses of wild medicinal plants in Prokletije Mountains (Montenegro). J Ethnopharmacol.133:97-107.

Mizushina Y, Nakanishi R, Kuriyama I, Kamiya K, Satake T, Shimazaki N, Koiwai O, Uchiyama Y, Yonezawa Y, Takemura $\mathrm{M}$, et al. 2006. $\beta$-Sitosterol-3- $O-\beta$-D-glucopyranoside: A eukaryotic DNA polymerase $\lambda$ inhibitor. J Steroid Biochem Mol Biol.99:100-107.

Nawwar MAM, Hussein SAM, Ayoub NA, Hofmann K, Linscheid M, Harms M, Wende K, Lindequist U. 2009. Aphyllin, the first isoferulic acid glycoside and other phenolics from Tamarix aphylla flowers. Die Pharmazie - An International Journal of Pharmaceutical Sciences.64:342-347.

Othman S, Hamzah AS, Aimi N, Lajis NH. 1996. Chemical constituents of Hedyotis dichotoma and their biological activity. Pertanika J Sci \& Technol.4:183-189.

Phan Duc T, Nguyen Thien TV, Jossang A, Nguyen Kim PP, Grellier P, Jaureguiberry G, Ton That Q. 2016. New wedelolides, (9R)-eudesman-9,12-olide $\delta$-lactones, from Wedelia trilobata. Phytochem Lett.17:304-309.

Piwowarski JP, Granica S, Kosiński M, Kiss AK. 2014. Secondary metabolites from roots of Geum urbanum L. Biochem Syst Ecol.53:46-50.

Pšenák M, Jindra A, Stano J, Suchý V. 1972. Vicianose from the root of Geum urbanum. Planta Med.22:93-96.

Shahani S, Monsef-Esfahani Hamid R, Saeidnia S, Saniee P, Siavoshi F, Foroumadi A, Samadi N, Gohari Ahmad R. 2012. Anti-Helicobacter pylori activity of the methanolic extract of Geum iranicum and its main compounds. Z Naturforsch, C: Biosci.67:172. 
Shigenaga S, Kouno I, Kawano N. 1985. Triterpenoids and glycosides from Geum japonicum. Phytochemistry.24:115-118.

Taylor K. 1997. Geum urbanum L. J Ecol.85:705-720.

Traoré-Coulibaly M, Ziegler HL, Olsen CE, Hassanata M-k, Pierre GI, Nacoulma OG, Guiguemdé TR, Christensen SBg. 2009. 19 $\alpha$-Hydroxy-3-oxo-ursa-1,12-dien-28-oic acid, an antiplasmodial triterpenoid isolated from Canthium multiflorum. Nat Prod Res.23:1108-1111. Xu H-X, Ming D-S, Dong H, But PP-H. 2000. A New Anti-HIV Triterpene from Geum japonicum. Chem Pharm Bull (Tokyo).48:1367-1369.

Xu H-X, Zeng F-Q, Wan M, Sim K-Y. 1996. Anti-HIV Triterpene Acids from Geum japonicum. J Nat Prod.59:643-645.

Yoshida T, Okuda T, Memon MU, Shingu T. 1985. Tannins of rosaceous medicinal plants. Part 2. Gemins A, B, and C, new dimeric ellagitannins from Geum japonicum. J Chem Soc, Perkin Trans 1.315-321.

Yuan J-Q, Yang X-Z, Miao J-H, Tang C-P, Ke C-Q, Zhang J-B, Ma X-J, Ye Y. 2008. New Triterpene Glucosides from the Roots of Rosa laevigata Michx. Molecules.13:2229-2237.

Zeng F-Q, Xu H-X, Sim K-Y, Gunsekera RM, Chen S-X. 1998. The anticoagulant effects of Geum japonicum extract and its constituents. Phytother Res.12:146-148. 